\title{
Development of Pratylenchus coffeae in Biochar Applied Soil, Coffee Roots and Its Effect on Plant Growth
}

\author{
Dwi Suci Rahayu ${ }^{1 *)}$ and Niken Puspita Sari ${ }^{1)}$ \\ ${ }^{1)}$ Indonesian Coffee and Cocoa Research Institute, J1. PB. Sudirman No. 90, Jember, Indonesia \\ ${ }^{*}$ Corresponding Author: ds.rahayu13@yahoo.com
}

\begin{abstract}
Biochar improve physical, chemical and biological properties of soil. It may also be used as botanical pesticides. The experiment was aimed to determine the effect of biochar on population development of parasitic nematode Pratylenchus coffeae. The experiment was carried out in Nematology Laboratory and in a greenhouse of Indonesian Coffee and Cocoa Research Institute (ICCRI), Jember, Indonesia. The experiment was arranged according to completely randomized design with six treatments of biochar concentrations, i.e. $4 \% ; 3 \% ; 2 \% ; 1 \% ; 0.5 \%$ and $0 \%$ dry weight of soil. Research results revealed that biochar application of $4.0 \%$ was effectively killed $74.5 \%$ of $P$. coffeae, while the lowest mortality level of $37.5 \%$ at biochar $0.5 \%$ treatment. In the greenhouse trial, application of biochar $4.0 \%$ was the most effective in suppressing the population of parasitic nematode in coffee seedlings. Application of biochar was also able to increase the growth and biomass of coffee seedlings.
\end{abstract}

Keywords: organic matter, biochar, coffee, parasitic nematode, Pratylenchus coffeae

\section{INTRODUCTION}

Parasitic nematodes have become serious issues for coffee plantation. One important parasitic nematodes infecting coffee plants, particularly Arabica coffee, is Pratylenchus coffeae. Until recently, some methods have been implemented to control the parasitic nematode and one of them is nematicide. Beside expensive, nematicides also may damage the environment and other organisms. Therefore, it is important to develop an environmentally and friendly alternative to control the nematode, such as by using organic substances. Improving soil organic matter content has been known to reduce the parasitic nematodes. Wiryadiputra (1995) had demonstrated that organic matters (e.g. manure, coffee husks, and compost) reduced approximately $70 \%$ of the parasitic nematode population. However, applied soil organic matter decompose quickly, eventually soil organic matter in soil decrease. Biochar has an ability to increase organic matter content in soil for a long time. According Qoyyum cit. Pujiyanto (2013), applied biochar may stabilize soil organic matter content in long term.

Biochar is one of soil revitalization material made from various types and forms of biomass including agricultural, forestry and plantation wastes such as pieces of wood, coconut shells, corn cobs, rice/bean husks, timber waste, sugarcane industrial wastes and other recyclable organic materials. Generally, the organic materials are burned incompletely or without oxygen, and most frequently using external heat source (pyrolysis). 
Biological charcoal formed from the heating process will produce activated carbon which contains calcium, magnesium and inorganic carbon (Lehmann \& Rondon, 2006).

Crop residues derived from agricultural, forestry and plantation wastes are relatively cheap potential sources of biomass energy. Most of these materials are no longer used and therefore, more affordable compared to other materials that were deliberately processed as materials for biomass (Horgan cit. Gani, 2009). Biochar can improve physical, chemical and biological characteristics of soil, including improving capacity of the soil to hold more water in order to reduce run-off and leaching of nutrients, increasing soil $\mathrm{pH}$, cation exchange capacity (CEC), organic $\mathrm{C}$, total $\mathrm{N}$ and reducing activity of $\mathrm{Fe}$ and $\mathrm{Al}$ ions resulting in increasing $\mathrm{P}$ content, increasing bacterial population, and composition, also activity of enzymes around plant roots (Rondon \& Lehmann, 2007; Wang et al., 2012).

Besides improving physical, chemical and biological characristics of soil, biochar can also function as a pesticide. The findings of Matondang et al. (2014) showed that application of $20 \mathrm{~g}$ coconut shell charcoal per plant reduced $32.3 \%$ of the disease caused by Phytophtora nicotianae in tobacco compared to control. Palm shell charcoal also reduced Fusarium oxysporum infection in chilli plants to $9.31 \%$; the percentage was lower than control (15.4\%) (Sinaga, 2011). Therefore, it is possible that biochar is able to reduce parasitic nematodes in coffee plantation. The purpose of this study was to investigate the effectiveness of biochar as a pesticide in controlling parasitic nematodes, particularly $P$. coffea both in soil and coffee roots and also on plant growth, and eventually can be used as an environmental-friendly control in coffee plantations.

\section{MATERIALS AND METHODS}

Biochar used in this study derived from burned log of woods. The biochar was ground and sieved into powder that could pass through $\pm 5 \mathrm{~mm}$ sieve. Pratylenchus coffeae nematodes were obtained from extraction of coffee infected by P. coffeae from Kaliwining Experimental Station of ICCRI, Jember, Indonesia. Improved Baermann method (Viglierchio \& Schmitt, 1983) was applied for the extraction so that the nematodes were still alive and healthy.

In vitro study was conducted in the Nematology Laboratory of ICCRI, Jember. The experiment was arranged based on completely randomized design with six treatments and each treatment was replicated four times. The treatments were $0.5 \%, 1 \%$, $2 \%, 3 \%$, and $4 \%$ biochar concentration per $10 \mathrm{~mL}$ of water as well as $0 \%$ (water without biochar as control). The $P$. coffeae nematodes were put into petridishes (diameter $9 \mathrm{~cm}$ ) containing $10 \mathrm{~mL}$ of water. The biochar with different concentration was then added to the petridish. There were 50 nematodes in each petridish (single treatment), regardless malefemale ratio of the organisms. Observations were conducted on the P. coffeae mortality in 24 hours after the treatment. Level of efficacy was calculated based on the Schneider-Orelli's formula (Ciba-Geigy, 1981), as follows:

$$
\% \text { Efficacy }=\left(\frac{\% \mathrm{MT}-\% \mathrm{MC}}{100-\% \text { of MC }}\right) \times 100
$$

where MT (mortality in treatment) and MC (mortality in control).

In vivo study was conducted to understand the influence of biochar on P. coffeae population and on growth of coffee plants and was conducted in a glass house of ICCRI. This study used completely randomized design. The treatments were $0.5 \%, 1 \%, 2 \%, 3 \%$, 
and $4 \%$ biochar concentration based on dried soil as well as $0 \%$ (no biochar as control). The treatments were replicated four times. One week after $P$. coffeae nematode inoculation, the biochar, according to each treatment, was poured around the coffee plants and covered $\pm 5 \mathrm{~cm}$ below the soil snoface.

Coffee seedlings used were the butterfly stage (two pairs of leaves) of S 795 Arabica coffee variety planted in polybags with planting medium volume of $300 \mathrm{~mL}$. The planting medium was a mixture of fine sand and manure with ratio of 2:1. The planting medium had been sterilized using an autoclave at the pressure of $2 \mathrm{~atm}$ at $120^{\circ} \mathrm{C}$ for four hours. Two weeks after the coffee seedlings was transfered into polybags, the seedlings were inoculated with 50 parasitic nematodes/ polybag and planted in $10 \mathrm{~cm}$ depth hole.

The focus of the observation was growth of the coffee seedlings which involved plant height, number of leaves, weight of fresh roots, weight of fresh and dried shoot as well as population of the nematodes at the end of the observation (three months after the application of biochar). Plant height and leaf number were observed for three months. The population of the nematodes was observed at the end of the observation (in soil sample and root tissue). The centrifuse method was conducted for extracting the nematodes. The infection of the nematodes was evaluated based on the percentage of root lesion or root rot. Data was analyzed using Duncan's multiple range test (DMRT) at 95\% level of confidence to determine the differences between treatments.

\section{RESULTS AND DISCUSSION}

This research results showed that biochar had significant influence on mortality of $P$. coffeae nematodes. Laboratory study showed that biochar with concentration $4.0 \%$ killed $74.50 \%$ P. coffeae nematodes. Concentration of $0.5 \%$ of biochar only killed $37.5 \%$ of the nematodes or the lowest percentage (Table 1). Several studies on effectiveness of biochar to control plant disease had been conducted previously. Active charcoal was able to control stem cancer of nutmeg by absorbing and binding the liquid produced by the plants from the wound caused by the disease (Anonymous, 2010). The liquid seeped through the wound caused by the cancer would enter or be bound in active hollow of biochar absorbing the liquid. The zig-zag active biochar hollow made it easier to absorb the liquid. Biochar was also effective to reduce root decaying disease due to Fusarium virguliforme (Rogovska et al., 2014).

In the study, the effectiveness of biochar to eradicate $P$. coffeae nematodes was similar to that of chemical nematicides. Three percent of biochar resulted in $62.50 \%$ mortality rate

Table 1. Effect of biochar on mortality of $P$. coffeae, 24 hours after treatment

\begin{tabular}{|c|c|c|}
\hline Treatment & Mortality, $\left.\%^{*}\right)$ & Efficacy level, $\%^{* * *}$ \\
\hline Biochar $4.0 \%(\mathrm{~A})$ & $74.50 \mathrm{a}$ & 74.50 \\
\hline Biochar $3.0 \%$ (B) & $62.50 \mathrm{ab}$ & 62.50 \\
\hline Biochar $2.0 \%(\mathrm{C})$ & $50.50 \mathrm{ab}$ & 50.50 \\
\hline Biochar $1.0 \%$ (D) & $50.00 \mathrm{ab}$ & 50.00 \\
\hline Biochar $0.5 \%(\mathrm{E})$ & $37.5 \mathrm{~b}$ & 37.5 \\
\hline Control $0(\mathrm{~F})$ & c 0 & \\
\hline
\end{tabular}


with $62.50 \%$ efficacy; moreover, $4.0 \%$ biochar killed $P$. coffeae nematodes with more than $70 \%$ level of efficacy. The findings of a study with the same method showed that $1 \mathrm{~g} / \mathrm{L}$ of carbofuran killed $67.5 \%$ of nematodes with the efficacy level of $61.6 \%$ (Wiryadiputra, 2010).

The in vivo study showed that $4.0 \%$ biochar was the most effective dosage to reduce the $P$. coffeae parasitic nematodes in coffee (Figure 1). There were approximately 118 P. coffeae paracitic nematodes in $4.0 \%$ biochar, while population of the organism in the control was 771 . It was predicted that biochar decomposition in the soil produced toxic compound that reduced the population of the $P$. coffeae parasitic nematodes. Wiryadiputra (1995) stated that adding organic substance and rice husk ash on coffee seedlings suppressed the parasitic nematode populations to approximately $70 \%$. It was related to the existence of agents that became the natural enemies of nematodes in organic substance. Toxic compounds for parasitic nematodes were produced from the decomposition of the organic materials and the effects of the growth of plants so that the plants became tolerant. Organic substance could create favorable conditions for root to grow which further accelerated the growth of roots and increased the use of soil nutrient. In other words, organic substance enhanced plant tolerance against damage caused by nematode.

Based on DMRT analysis, it was found that $0-4 \%$ biochar influenced on population of $P$. coffeae in the roots of Arabica coffee seedlings. The higher biochar concentration was, the lower population of the P. coffeae nematodes was. Yet, there was one treatment, $2.0 \%$ biochar, where the average population of $P$. coffeae nematodes was higher than the $1.0 \%$ and $0.5 \%$ nematodes. It was predicted that eventhough the biochar was not applied, the $P$. coffeae nematodes would insert into the root tissue. According to Jones et al. (2013), $P$. coffea attacks epidermis, endodermis and cortex of roots, particularly young roots. The observation revealed that the population of $P$. coffeae in the soil was fewer than that in the roots. The population of P. coffeae in the soil in the treatments of $0 \%, 0.5 \%$, $1.0 \%, 2.0 \%$ and $4.0 \%$ were $0 \%, 112.5 \%$, $112.5 \%, 168.75 \% 0 \%$ and $37.5 \%$, respectively (Figure 1). The average population of $P$. coffeae in each of the treatments were not consistent. It happened probably since most of the $P$. coffeae nematodes had entered Arabica coffee roots so that their population in the soil was fewer than that in the roots.

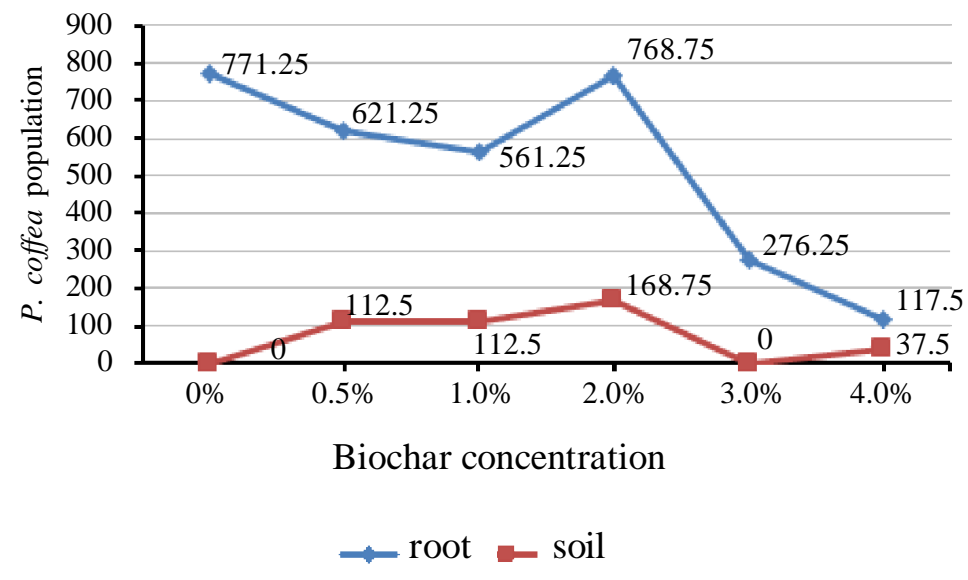

Figure 1. Effect of biochar on P. coffeae population in Arabica coffee seedlings 
The percentage of root damage in $0.5 \%$ $4.0 \%$ biochar was between $55 \%$ and $76.3 \%$ (Figure 2). Based on the findings, biochar did not have any influence in the percentage of root damage (lroot lesion). It was due to microorganism in the soil such as bacteria and fungi. According to Jones et al. (2013), Pratylenchus infestation result in root damage which eventually decrease plant growth, increase water stress susceptibility and develop brownish root lesion. Decreased root growth is followed by decomposed root caused by secondary attack by fungi and bacteria. It generally would also be followed by flea infection (Planococcus spp.) covered by a type of fungus called Diacanthodes spp. (Pfaltzer \& Fluiter cit. Wiryadiputra, 1995). In plantation, nematode infection was worsened by secondary infection from other pathogens; wilt disease caused by Rhisoctonia solanacearum and Fusarium oxysporum increased because of Meloidogyne incognita nematodes (Carneiro et al., 2010).

Root demage caused by nematode infection had direct influence towards the growth of plants. The plants would not grow well since the damaged roots could not work as it should. Some effects of nematode in- fection were stunted plant growth (stunted, wilt, even death) and decreasing yield (Dropkin, 1991). Pradana (2014) stated that the damage on the roots was affected by population of nematodes in the soil around the plants. Brooks (2004) had similar idea that the percentage of damage in banana roots had positive correlation to the population of Pratylenchus goodeyi nematodes. The higher population of $P$. goodeyi nematodes was, the more damage found on the banana roots.

Based on DMRT analysis, biochar significantly influenced number of leaf and height of the plants. During the testing on the glass house, the number of leaf and the height of the coffee seedling in the $2.0 \%$ biochar treatment were higher than those in other treatments (Figure 3). The findings of similar studies also revealed that biochar significanly influenced plant height and number of leaves of 40, 60 and 80-days mahagony (Helmi, 2014). Lehmann \& Rondon (2006) mentioned that biochar may improve the growth and available nutrition in cowpeas (Vigna unguiculata) and rice (Oryza sativa L.) although the $\mathrm{N}$ concentration on the leaves decreased and the absorption of $\mathrm{P}, \mathrm{K}, \mathrm{Ca}, \mathrm{Zn}$ and $\mathrm{Cu}$ by the plants increased.

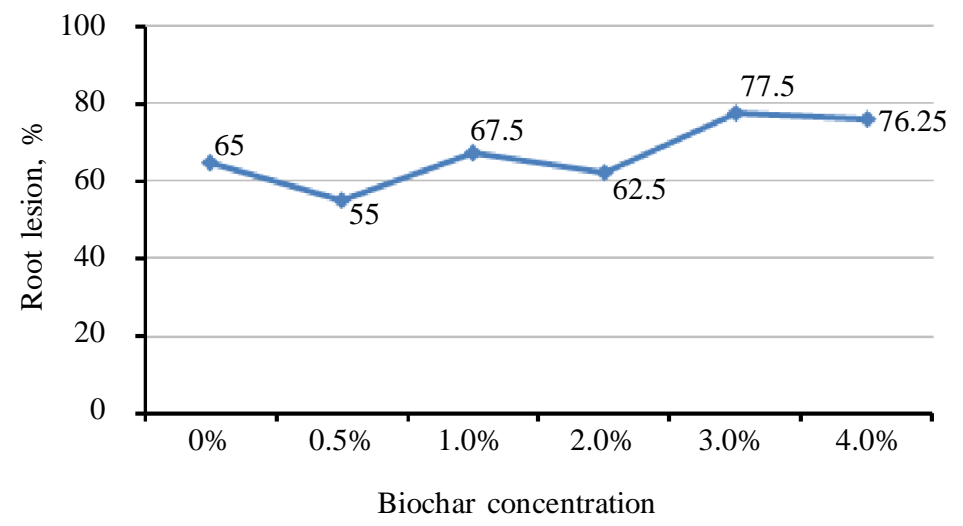

Figure 2. Effect of biochar on root lession caused by P. coffeae of Arabica coffee seedlings 

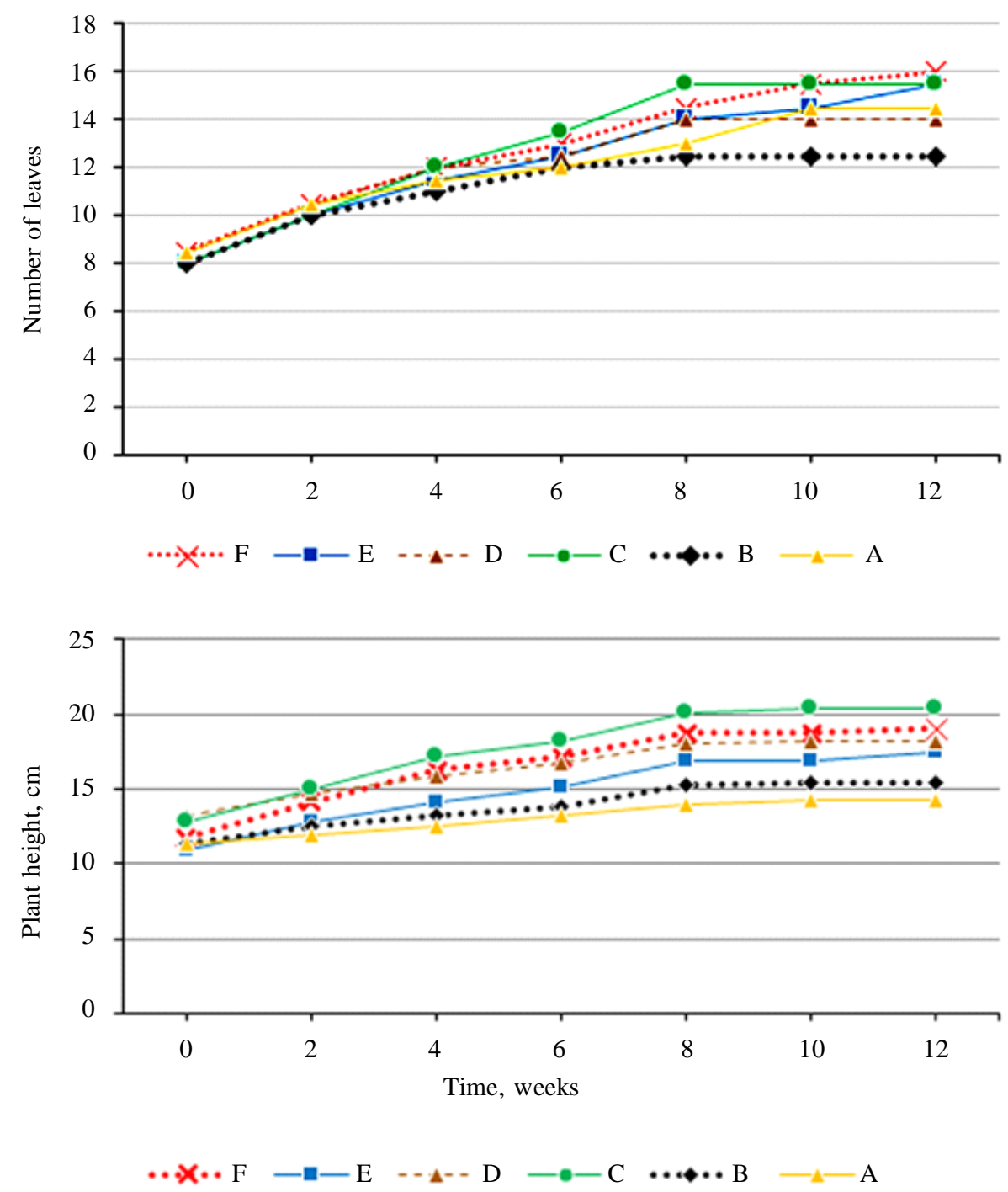

Figure 3. Effect of biochar on number of leaves (A) and height (B) of Arabica coffee seedling Notes: (Explanation of treatment codes see Table 1)

Table 2 showed that $2.0 \%$ biochar treatment resulted in higher weight of fresh roots, fresh and dry shoots than the $3.0 \%, 1.0 \%$ and $0.5 \%$ biochar treatment, but not significantly different from the control. Nonetheless, there was a tendency that the $2.0 \%$ biochar treatment resulted in higher fresh roots, fresh and dry shoots weight than the control. The findings of Carter et al. (2013) indicated that applying $50-150 \mathrm{~g} / \mathrm{kg}$ of biochar promoted growth and biomass of mustard (Brassica chinensis). It was related to increasing cation content $(\mathrm{K}, \mathrm{Ca}$, and $\mathrm{Mg})$ and $\mathrm{pH}$ in the soil. The high nutrient available for the plants is the result of increased nutrients directly from the biochar and increasing nutrient retention (Lehmann et al., 2003). Beside that, biochar also increased the reach of plant roots making it easier for plants to get nutrients and water (Dou et al., 2012). 
Table 2. Effect of biochar on fresh weight of roots and shoot, and shoot dry weight of Arabica coffee seedlings

\begin{tabular}{lccc}
\hline \multirow{2}{*}{ Treatment } & \multicolumn{2}{c}{ Fresh weight, $\mathrm{g}$} & Dry weight of shoot, $\mathrm{g}$ \\
\cline { 2 - 4 } & Roots & Shoot & $0.60 \mathrm{c}$ \\
Biochar $4.0 \%$ & $0.59 \mathrm{~b}$ & $1.93 \mathrm{c}$ & $0.80 \mathrm{bc}$ \\
Biochar 3.0\% & $1.02 \mathrm{ab}$ & $2.58 \mathrm{bc}$ & $1.44 \mathrm{a}$ \\
Biochar 2.0\% & $1.31 \mathrm{a}$ & $4.60 \mathrm{a}$ & $1.11 \mathrm{ab}$ \\
Biochar $1.0 \%$ & $1.28 \mathrm{a}$ & $3.54 \mathrm{ab}$ & $1.09 \mathrm{ab}$ \\
Biochar $0.5 \%$ & $1.10 \mathrm{ab}$ & $3.33 \mathrm{abc}$ & $1.19 \mathrm{ab}$ \\
Control & $1.14 \mathrm{ab}$ & $3.88 \mathrm{ab}$ & \\
\hline Notes: Values within the same column followed by the same letter(s) are not different according to Duncan's Multiple Range &
\end{tabular}

Basically, all organic substances applied to the soil improved various functions of the soil such as retention from various essential nutrients for the growth of plants. Lehmann (2007) mentioned that biochar was more effective to maintain the amount of nutrients in the soil compared to other organic substance such as leaves, compost or manure. Biochar also sustained that could not be retained by other organic substance for the soil. As addition, biochar provided suitable growing media and elevated activities of different soil biota. It increased the level of growing susbtance that along with the nutrients in the soil simultaneously improved the growth and production of plants (Pujiyanto, 2013).

\section{CONCLUSION}

Biochar application at concentration range of $3-4 \%$ in laboratory experiment controlled $P$. coffeae at level of effectiveness 62.5-74.5\%. Application of biochar at concentration range of $0.5-4 \%$ could control $P$. coffeae at seedling stage. Application of biochar 2\% produced higher fresh weight of root and shoot, and dry weight of shoot larger than control.

\section{ACKNOWLEDGMENT}

The author would like to thank Dr. John Bako Baon and Ir. Soekadar Wiryadiputra, SU for their suggestions.

\section{REFERENCE}

Anonim (2010). Arang tempurung sebagai pengendali pestisida. Warta Penelitian dan Pengembangan Pertanian, 32.

Anonim (2011). Pengaruh Biochar terhadap Sifat Kimia, Fisika dan Biologi Tanah. Skripsi, Universitas Lampung, Lampung.

Borrow, C.J. (2012). Biochar: Potential for countering land degradation and for improving agriculture. Applied Geography, 34, 21-28.

Brooks, F.E. (2004). Plant-parasitic nematodes of banana in American Samoa. Nematropica, 34, 65-72.

Ciba-Geigy (1981). Manual for Field Trials In Plant Protection. Second edition revised and enlarged. Werner Puntener, Agic. Div, Ciba-Geigy Limited, Basle, Switzerland.

Carter, S.; S. Shackley; S. Sohi; Tan Boun Suy $\&$ S. Haefele (2013). The impact of biochar application on soil properties and plant growth of pot grown lettuce (Lactuca sativa) and cabbage (Brassica chinensis). Agronomy, 3, 404-418. 
Carniero, F.F.; M.A.P.Ramalho \& M.J.Z. Pereira (2010). Fusarium oxysporum and Meloidogyne incognita interaction in common bean. Crop Breeding and Applied Biotechnology, 10, 271-274.

Dou, L.; M. Komatsuzaki \& M. Nakagawa (2012). Effects of biochar, mokusakueki and bokashi application on soil nutrient, yields and qualities of sweet potato. International Research Journal of Agricultural Science and Soil Science, 2,318-327.

Elad, Y.; E. Cytryn; Y.M. Harel; B. Lew \& E.R. Graber (2011). The biochar effect: plant resistance to biotic stresses. Phytopathologia Mediterranea Review, 50, 335-349.

Gani, A. (2009). Potensi arang hayati "Biochar" sebagai komponen teknologi perbaikan produktivitas lahan pertanian. Iptek Tanaman Pangan, 1, 33-48.

Helmi (2014). Pengaruh jenis biochar dan konsentrasi pupuk Agrodyke terhadap pertumbuhan bibit mahoni (Swietenia macrophylla King). Jurnal Biologi Edukasi, 6, 71-77.

Jones, J.T.; A. Haegeman; E.G.J. Danchin; H.S. Gaur; J. Halder; M.G.K. Jones; T. Kikuchi; R.M. Lopez; J.E.P. Rius; W.M.L.Wesemael \& R.N.Perry (2013). Top 10 plant-parasitic nematodes in molecular plant pathology. Molecular Plant Pathology Review, 14, 946-961.

Lehmann, J.; J.P. da Silva; C. Steiner; T. Nehls; W. Zech \& B. Glaser (2003). Nutrient availability and leaching in an archaeological Anthrosol and a Ferralsol of the Central Amazon basin: fertilizer, manure and charcoal amendments. Plant and Soil, 249, 343-357.

Lehmann, J. \& M. Rondon (2006). Biochar soil management on highly weathered soils in the humid tropics. p. 517-530. In: Biological Approaches to Sustainable Soil Systems (Norman Uphoff et al. Eds.). Taylor \& Francis Group PO Box 409267. Atlanta.
Lehmann, J. (2007). Bio-energy in the black. Frontiers in Ecology and The Environment, 5, 381-387.

Matondang, I.H.; L. Lubis \& M. Iskandar (2014). Uji efektivitas Trichoderma harzianum dan pemberian arang batok kelapa sebagai pengendalian hayati penyakit lanas (Phytophtora nicotianae de Hann.) pada tanaman tembakau Deli. A Jurnal Online Agroekoteknologi, 2, 813-821.

Ogbonnaya, U \& K.T. Semple (2013). Impact of biochar on organic contaminants in soil: A tool for mitigating risk? Agronomy Review, 3, 349-375.

Pradana, A.P.; D. Putri \& A. Munif (2014). Analisis populaasi nematoda pada lahan tanaman tomat dengan sistem tanam monokultur dan polikultur. Prosiding Seminar Nasional PFI Komda Joglosemar, Yogyakarta, 2014, 147-155.

Pujiyanto (2013). Respons tanaman kopi Arabika pada tanah Andisol terhadap aplikasi bahan organik. Pelita Perkebunan, 29, 182-196.

Rogovska, N.; D.A. Laird; L. Leandro \& D. Aller (2014). Biochar effects on severity soybean root disease caused by Fusarium vilguliforme. ASA, CSSA \& SSSA International Annual Meeting, Long Beach, CA.

Rondon, M.A. \& J. Lehmann (2007). Biological nitrogen fixation by common beans (Phaseolus vulgaris L.) increases with biochar additions. Biology and Fertility of Soils, 43, 699-708.

Santi, L.P. \& D.H. Goenadi (2010). Pemanfaatan biochar sebagai pembawa mikroba untuk pemantap agregat tanah Ultisol dari Taman Bogo-Lampung. Menara Perkebunan, 78, 52-60.

Sinaga, M.H. (2011). Pengaruh Bio VA-Mikoriza dan Pemberian Arang Terhadap Jamur Fusarium oxysporum capsici pada Tanaman Cabai (Capsicum annum L.) di Lapangan. Skripsi. Universitas Sumatera Utara, Medan. 
Viglierchio, D.R. \& R.V. Schmitt (1983). On the methodology of nematode extraction from field samples: Baermann funnel modifications. The Journal of Nematology, 15, 438-444.

Wang, T.T; J. Cheng; X.J. Liu; W. Jiang; C.L. Zhang \& X.Y. Yu (2012). Effect of biochar amendment on the bioavailability of pesticide chlorantraniliprole in soil to earthworm. Ecotoxicology and Environmental Safety, 83, 96-101.

Wiryadiputra, S.; E. Sulistyowati \& Soenaryo (1987). Penggunaan bahan organik dan abu sekam padi untuk mengendalikan nematoda parasit di pembibitan kopi. Pelita Perkebunan, 2, 146-151.

Wiryadiputra, S, (1995). Nematoda parasit kopi di Indonesia dan alternatif pengendaliannya. Warta Puslit Kopi dan Kakao, 3, 120-128.

Wiryadiputra, S.; W. Anggraini; J. Waluyo \& Pujiastuti (1995). Pengaruh ekstrak biji sirsak (Annona muricata) terhadap perkembangan nematoda Pratylenchus coffeae pada tanaman kopi Arabika. Pelita Perkebunan, 26, 156-168.

$* * 0 * *$ 